\title{
REKAYASA MEDIA TANAM PADA SISTEM PENANAMAN HIDROPONIK UNTUK MENINGKATKAN PERTUMBUHAN TANAMAN SAYURAN
}

\author{
M. Aksa1), Jamaluddin P 2), Subariyanto2) \\ ${ }^{1}$ Alumni Program Studi Pendidikan Teknologi Pertanian \\ 2 dan ${ }^{3}$ Dosen PTP FT UNM \\ aksaunm@yahoo.co.id
}

\begin{abstract}
The aim of this research is to improve the growth of vegetable planting through Plant Media Modifying in Hydroponic Planting Systems. This research is an experimental research by using a form of design randomized group (RAK) with 3 treatments and 3 different concentrations, and 3 controls with the same concentration. The experimental method is done with four repetitions. Thus the number of plants being studied is 48 sample. The results showed 3 models of Plant Media Modifying in hydroponic planting system that has been done in this study, overall appears giving contribution to increasing the growth of vegetable planting when compared with group controls. The combination of husked mixture and hull of rice appears the highest contribution, while the lowest contribution toward the growth of vegetable planting is shown through a mixture of husked charcoal and fern roots.
\end{abstract}

\section{Keywords: Modifying, Plant Media, Hydroponics, Growing, Vegetables}

\section{PENDAHULUAN}

Sayur merupakan sumber makanan yang mengandung gizi lengkap dan sehat. Sayur berwarna hijau merupakan sumber kaya karoten (provitamin A). Semakin tua warna hijaunya, maka semakin banyak kandungan karotennya. Salah satu sayuran yang sering dikonsumsi oleh masyarakat adalah sawi hijau (Brassica Juncea L). Sawi hijau, dapat dikategorikan kedalam sayuran daun. Sawi, memiliki nilai ekonomis tinggi setelah kubis dan brokoli. Selain itu, tanaman ini juga mengandung mineral, vitamin, protein dan kalori. Oleh karena itu tanaman ini menjadi komoditas sayuran yang cukup populer di Indonesia (Rukmana, 1994)

Menurut data Badan Pusat Statistik (2014), produksi sawi di Indonesia dari tahun 2009-2013 mengalami fluktuasi yang dapat dilihat secara berturut-turut (Badan Pusat Statistik, 2013) : 562,838 ton (2009), 583,770 ton (2010), 580,969 ton (2011), 594,934 ton (2012) dan 600,961 (2013). Direktur Pengembangan Usaha dan Investasi Ditjen Pengolahan dan Pemasaran Hasil Pertanian (PPHP) Kementerian Pertanian menyatakan saat ini konsumsi buah dan sayur nasional kurang lebih $41,9 \mathrm{~kg} / \mathrm{kapita} / \mathrm{tahun}$. Tingkat konsumsi tersebut masih di bawah standar kecukupan pangan terhadap buah dan sayur yang ditetapkan FAO yakni 73 kg/kapita/tahun (Ditjen PPHP, 2014)

Rendahnya tingkat konsumsi tersebut selain karena rendahnya kesadaran masyarakat akan pentingnya mengomsumsi buah dan sayur juga berkaitan erat dengan minimnya tingkat produksi pangan yang dialami oleh petani Indonesia terutama sayuran dan 
buah. Hal tersebut disebabkan beberapa alasan, seperti penerapan teknologi budidaya yang masih sederhana, ataupun karena lahan untuk bercocok tanam semakin berkurang. Kebanyakan teknik budidaya yang dilakukan para petani di Sulawesi Selatan, masih bersifat konvensional dan tidak memperhatikan teknik budidaya yang baik, teknologi juga masih kurang diterapkan oleh petani, sehingga kualitas dan kuantitas produksi yang dihasilkan masih tergolong rendah.

Kebutuhan sayuran yang terus meningkat berbanding lurus dengan nilai ekonomisnya yang semakin tinggi. Namun, kenaikan ini tidak diimbangi dengan pertambahan luas lahan yang digunakan untuk penanaman sayuran. Hal ini menjadi kendala. Mengatasi hal tersebut ditempuh berbagai cara untuk meningkatkan produktivitas tanaman, dengan harapan dari lahan yang sempit dapat dihasilkan produksi yang tinggi. terutama di wilayah perkotaan yang memiliki keterbatasan lahan kosong. Oleh karena itu, diperlukan suatu sistem penanaman yang dapat menghemat penggunaan lahan, tetapi mampu memproduksi sayuran yang sehat berkualitas. Salah satunya dengan sistem hidroponik, baik tanpa atau dengan rumah kaca (green house).

Dalam tiga tahun terakhir perkebunan hidroponik bermunculan. Teknologi ini sangat banyak memberikan keuntungan terutama dapat menghemat biaya investasi sekitar $38 \%$, dan mampu menghasilkan sayuran yang dipersyaratkan pasar (Rahimah, 2012). Perlakuan media tanam yang sesuai membuat tanaman sehat sehingga dapat bertahan dari serangan hama dan penyakit.

Media tanam merupakan salah satu unsur yang paling berperan dalam pertumbuhan tanaman, selain sebagai penopang akar tanaman, ketersediaan unsur hara yang terdapat dalam media tanam sangat dibutuhkan. Dalam budidaya tanaman terutama sayuran media tanaman merupakan faktor penentu berhasil tidaknya suatu budidaya. Selain itu media tanaman juga ikut menentukan kualitas dan kuantitas tanaman yang dihasilkan.

Media tanam yang digunakan sebagai media tumbuh tanaman hidroponik banyak jenisnya. Syarat media tanam hidroponik yaitu dapat dijadikan tempat berpijak tanaman, mampu mengikat air dan unsur hara yang dibutuhkan untuk pertumbuhan tanaman, mempunyai drainase dan aerasi yang baik, dapat mempertahankan kelembaban disekitar akar tanaman, dan tidak mudah lapuk (Agoes, 1994).

Melihat betapa pentingnya media tanam terhadap pertumbuhan tanaman maka rekayasa media tanam secara hidroponik, dengan sampel tanaman sawi hijau, penting dikembangkan lebih lanjut untuk melihat tentang pertumbuhan tanaman sawi hijau, maka dalam penelitian ini dikembangkan 3 (tiga) macam media tanam, yaitu campuran antara arang sekam dengan sekam padi, sekam padi dengan akar pakis, serta arang sekam dengan akar pakis. Sehingga dari penelitian ini diperoleh petunjuk mengenai media tanam yang sesuai untuk pertumbuhan tanaman sayur.Tujuan yang ingin dicapai dalam penelitian ini untuk mengetahui pengaruh media tanam campuran antara arang sekam dengan sekam padi, sekam padi dengan akar pakis, dan arang sekam dengan akar pakis terhadap pertumbuhan sawi hijau secara hidroponik. 


\section{METODOLOGI PENELITIAN}

Jenis penelitian ini merupakan penelitian eksperimen, menggunakan Rancangan Acak Kelompok (RAK) dengan 3 perlakuan dan masing-masing 3 konsentrasi berbeda, serta terdapat 3 kontrol, masing-masing 4 ulangan sehingga jumlah tanaman yang diamati 48. Perlakuan dalam percobaan ini yaitu Perlakuan I arang sekam + sekam padi, masing-masing $75 \%+25 \%, 50 \%+50 \%$, $25 \%+75 \%$ dengan 4 kali ulangan, Perlakuan II sekam padi + akar pakis, masing-masing $75 \%+25 \%, \quad 50 \%+50 \%$, $25 \%+75 \%$ dengan 4 kali ulangan, Perlakuan II arang sekam + akar pakis, masing-masing $75 \%+25 \%, \quad 50 \%+50 \%$, $25 \%+75 \%$ dengan 4 kali ulangan dan kontrol arang sekam, sekam padi, dan akar pakis dengan 4 kali ulangan.

Data diperoleh dari nilai pengamatan parameter tinggi tanaman, jumlah daun, panjang daun dan panjang akar dihitung pada 0, 7, 14, 21, 28 hari setelah tanam (HST). selanjutnya data tersebut di analisis dengan menggunakan analisis varian (ANOVA) dan dilanjukan dengan uji Duncan Multiple Range Test (DMRT).

\section{HASIL DAN PEMBAHASAN}

\section{Tinggi Tanaman}

Hasil penelitian menunjukkan perbedaaan nilai rata-rata tinggi tanaman pada setiap perlakuan. Hal ini disebabkan adanya perbedaan pemberian campuran media tanam pada setiap media dan kontrol. Perlakuan yang menunjukkan tinggi tanaman ideal yaitu diperoleh dari kombinasi media tanam antara arang sekam dan sekam padi. Kondisi ini mungkin dikarenakan pada kombinasi media tanam antara arang sekam dan sekam padi mempunyai aerasi yang baik sehingga sirkulasi udara berjalan dengan baik.

Hasi penelitian yang dilakukan oleh Perwtasari, dkk. (2012) tampak sejalan dengan hasil penelitian ini. Dimana hasil penelitiannya telah berhasil mengungkapkan bahwa perlakuan komposisi media tanam memberikan hasil yang berbeda nyata pada tinggi tanaman sawi. Selain itu,budidaya tanaman sawi pada sistem penanaman hidroponik selain memerlukan unsur hara dan media tanam yang digunakan juga harus memiliki porositas yang baik agar udara dan nutrisi dalam akar dapat menyerap nutrisi dengan optimal.

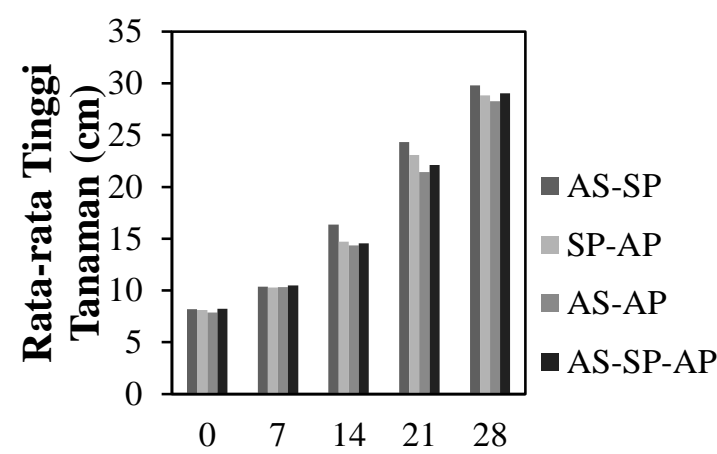

Lama Penanaman (hari)

Gambar 1. Nilai rata-rata perubahan tinggitanaman sawi selama dalam prosespenanaman dengan sistem hidroponikpada berbagai variasi campuran media tanam

\section{Jumlah Daun}

Hasil rekayasa media tanam campuran antara arang sekam dan sekam padi menunjukkan adanya perbedaan jumlah daun yang relatif banyak. Hal ini disebabkan pada hasil rekayasa media tanam antara arang sekam dan sekam padi selain karena memiliki perpaduan yang baik juga dapat 
memberikan daya pegang akar yang lebih bagus serta memberikan sirkulasi udara yang baik untuk penyerapan nutrisi keseluruh akar tanaman.

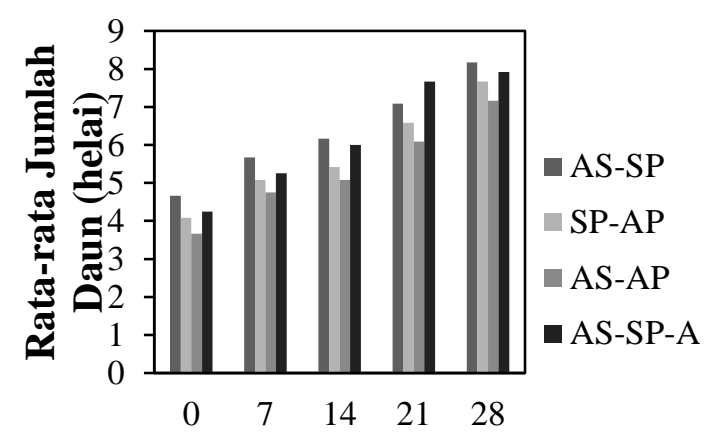

Lama Penanaman (hari)

Gambar 2. Nilai rata-rata perubahan jumlah daun tanaman sawi selama dalam proses penanaman dengan sistem hidroponik pada berbagai variasi campuran media tanam

\section{Panjang Daun}

Perubahan panjang daun tanaman sawi baru mulai ditunjukkan pada hari selanjutnya, kondisi tersebut dikarenakan pada setiap hasil rekayasa campuran media tanam yang berbeda memberikan respon yang berbeda terhadap pertumbuhan tanaman sawi. Hasil rekayasa media tanam pada campuran antara arang sekam dan sekam padi menunjukkan panjang daun yang dapat dijadikan persentase dalam pertumbuhan tanaman sawi, dimana panjang daun berbanding lurus dengan pertumbuhan tanaman. Dengan demikian pertumbuhan yang terjadi pada campuran media arang sekam dan sekam padi memberikan hasil yang terbaik.

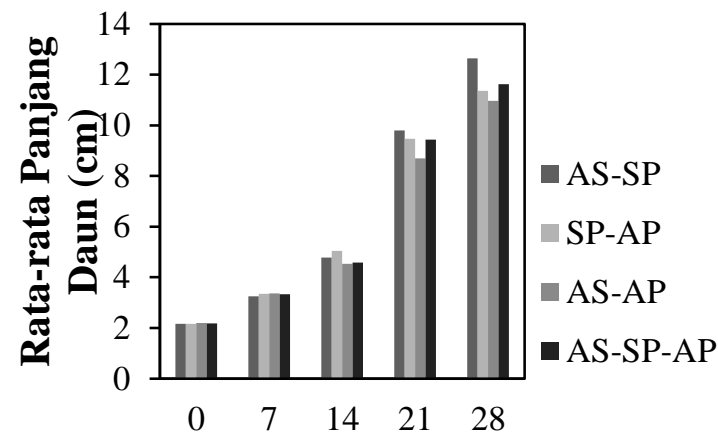

Lama Penanaman (hari)

Gambar 3. Nilai rata-rata perubahan panajang daun tanaman sawi selama dalam proses penanaman dengan sistem hidroponik pada berbagai variasi campuran media tanam

\section{Panjang Akar}

Perbedaan perubahan panjang akar tanaman sawi dipengaruhi oleh rekayasa media tanaman, dimana dari hasil penelitian diperoleh gambaran bahwa perlakuan media tanam yang berbeda akan memberikan pengaruh yang berbeda pula terhadap perkembangan akar tanaman sawi. Pada hari ke-28, perlakuan kontrol pada konsentrasi masing-masing $50 \%$ diperoleh perubahan panjang akar yang paling besar, kemudian diikuti oleh perlakuan pada media arang sekam dan sekam padi yang memberikan respon yang hampir sama. Demikian pula halnya pada konsentrasi campuran $25 \%$ dengan $75 \%$, kedua perlakuan ini memberikan pertumbuhan akar yang baik pula. Dengan demikian, maka diperoleh gambaran bahwa pada perlakuan kontrol dan rekayasa media campuran antara arang sekam dan sekam padi memberikan pertumbuhan terbaik yang ditunjukkan dengan semakin kokohnya pertumbuhan akar tanaman sawi. Hal ini dapat menunjang pertumbuhan tanaman sawi disebabkan 
kemampuan penyerapan nutrisi oleh akar menjadi semakin meningkat.

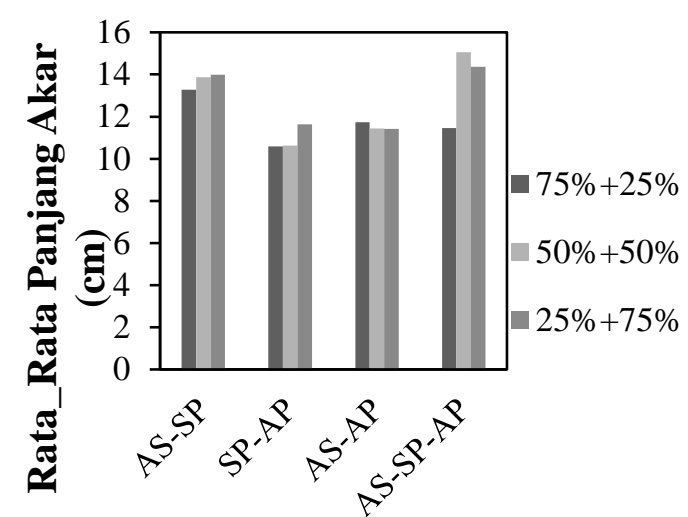

Campuran Rekayasa Media Tanam (\%)

Gambar 4.Nilai rata-rata perubahan panjang akar tanaman sawi selama dalam proses penanaman dengan sistem hidroponik pada berbagai variasi campuran media tanam

\section{KESIMPULAN} adalah :

Kesimpulan dari hasil penelitian ini

1. Pengaruh perlakuan campuran antara media arang sekam dengan sekam padi terhadap pertumbuhan tanaman sawi hijau secara hidroponik memberikan kontribusi atau pengaruh yang signifikan dibandingkan dengan perlakuan kontrol, berdasarkan hasil rata-rata pertumbuhan tinggi tanaman, jumlah daun, panjang daun dan panjang akar sawi hijau.

2. Pengaruh perlakuan campuran media tanam antara sekam padi dengan akar pakis terhadap pertumbuhan tanaman sawi hijau secara hidroponik memberikan kontribusi atau pengaruh yang signifikan kedua dibandingkan dengan perlakuan kontrol, berdasarkan hasil rata-rata pertumbuhan tinggi tanaman, jumlah daun, panjang daun dan panjang akar sawi hijau.

3. Pengaruh perlakuan campuran media tanam antara arang sekam dengan akar pakis terhadap pertumbuhan tanaman sawi hijau secara hidroponik memberikan kontribusi atau pengaruh yang terkecil dibandingkan dengan perlakuan kontrol, berdasarkan hasil rata-rata pertumbuhan tinggi tanaman, jumlah daun, panjang daun dan panjang akar sawi hijau

\section{DAFTAR PUSTAKA}

Agoes, S.. 1994. Aneka Jenis Media Tanam dan Penggunaannya. Penebar Swadaya. Jakarta.

Badan Pusat Statistik (BPS) Republik Indonesia, 2014. Produksi Sawi di Indonesia. Dikutip Dari: www.bps.indonesia.co.id 16 April 2014.

Direktur Pengembangan Usaha dan Investasi Ditjen Pengolahan dan Pemasaran Hasil Pertanian (PPHP) Kementerian Pertanian Indonesia. 2014. Dikutip Dari: www.antaranews.com 23 April 2014.

Perwtasari, dkk. 2012. Pengaruh perlakuan media tanam terhadap pertumbuhan tanaman sawi. Dikutip Dari: www.gudangilmu.com 20 mei 2015.

Rahimah, D. S., 2012. Hidroponik Dibawah Langit. TRUBUS No. 513 Edisi Agustus 2012/XLIII. 
Rukmana, R., 1994. Bertanam Petsai

danSawi.

Kanisius.

Yogyakarta. 